\title{
Complement C3a Measurement
}

National Cancer Institute

\section{Source}

National Cancer Institute. Complement C3a Measurement. NCI Thesaurus. Code C80175.

The determination of the amount of complement C3a present in a sample. 